\title{
The Stock Exchange Member: Liability for Violation of Stock Exchange Rules ${ }^{\dagger}$
}

\author{
Nicholas Wolfson* \\ Thomas A. Russo" *"*
}

The need to adequately protect investors has prompted the idea that civil liability of exchange members for damages resulting from violation of exchange rules might be an effective supplement to selfregulation. The scope of civil liability is uncertain, however, because little case law has evolved. Messrs. Wolfson and Russo describe the self-regulatory system, analyze the scant case law dealing with civil liability, and propose a test of liability which focuses on the nature of the rule violated and its relationship to the Securities Exchange Act of 1934. Finally, they set forth several hypothetical examples of the way in which the proposed test should be applied and conclude that invoking civil liability in accordance with this test would significantly increase the protection afforded investors who deal with members of stock exchanges.

Under the Securities Exchange Act of 1934 the stock exchanges are self-regulatory associations with important responsibilities and powers. $^{1}$ The hearings and studies which preceded enactment of the 1934

$\dagger$ The Securities and Exchange Commission, as a matter of policy, disclaims rcsponsibility for any private publications by any of its employees. The views expressed herein are those of the authors and do not necessarily reflect the views of the Commission or of the authors' colleagues on the Commission's staff.

* Assistant Director, Division of Trading and Markets, Securities and Exchange Cominission. A.B. 1953, Columbia University; J.D. 1956, Harvard University.

** Staff Attorney, Division of Trading and Markets, Securities and Exchange Commission. A.B. 1965, Fordham University; M.B.A. 1969, J.D. 1969, Corncll University.

1. The term "exchange" means any organization, association, or group of persons, whether incorporated or unincorporated, which constitutes, maintains, or provides a market place or facilities for bringing together purchasers and sellers of securities or for otherwise performing with respect to securities the functions commonly performed by a stock exchange as that term is generally understood, and includes the market place and the inarket facilities maintained by such exchange.

Securities Exchange Act of 1934 \$ 3(a)(1) [hereinafter cited as 1934 Act], 15 U.S.C. $\S 78 \mathrm{c}(\mathrm{a})(1)$ (1964). The New York Stock Exchange (NYSE) until February 18, 1971, was an unincorporated association. One author had observed with respect to an unincorporated association: "It would seem that meınbers of the exchange are individually [and] jointly liable for obligations incurred by the officers or governors of the ex- 
Act criticized the private club atmosphere of the New York Stock Exchange (NYSE). ${ }^{2}$ A crucial purpose of the Act was to transform the exchanges from private trade associations into responsible self-regulatory organizations imbued with public purposes and responsibilities. ${ }^{8}$ Sections $6,10,11,12$ and 19 of the Act ${ }^{4}$ reflect this intent and articulate the quasi-governmental purpose of exchanges. ${ }^{5}$

The 1934 Act states that stock transactions upon exchanges are "affected with a national public interest" which requires that these transactions be adequately regulated in all aspects. ${ }^{6}$ To effect this broad regulatory purpose, section 5 of the 1934 Act provides that no broker or dealer may use any facility ${ }^{\tau}$ of an exchange to effect security transactions unless the exchange is registered as a national securities exchange or is exempted therefrom because of its limited volume. ${ }^{8}$ Section 6 sets forth the procedures and requirements for registration of exchanges. $^{0}$ An exchange may be registered by filing a registration statement with the Securities and Exchange Commission. The statement, in such form as the Commission may require, must be accompanied by

change acting within the scope of their powers as defined by the Constitution and rules." C. Meyer, The LaW of Stock Brokers and Stock Exchanges 29 (1931). Incorporation is an attempt to insulate members from liability for violations by the exchange itself of its duties; it, of course, has no bearing upon the liability of stock exchange members for violations by them of stock exchange rules. For a discussion of the law dealing with liability of an exchange, see authorities cited note 26 infra.

2. H.R. REP. No. 1383, 73d Cong., 2d Sess. 15 (1934). The objects of the NYSE are to furnish exchange rooms for the transaction of business, to "maintain high standards of commercial honor ... among its members [and to] promote ... just and eqnitable principles of trade ...." NYSE Const. art. I, $\& 2$. The Constitution further provides that a person shall not become a member unless he agrees in writing to abide by the Constitution and the rules thereunder, NYSE Const. art. IX, $\S 6$. A member or member organization who has violated a rule or constitutional provision may be suspended or expelled by the Board of Governors. NYSE Const. art. XIV; $\$ 6$. Members are subject to the same discipline for acts or omissions of their firm. NYSE Const. art. XIV, \& 16.

3. H.R. REP. No. 1383, 73d Cong., 2d Sess. 15 (1934). The self-regulatory structure appeared to be partially a result of the belief that self-regulation would lessen the work load of the Federal Government and decrease the size of the federal bureaucracy. See Hearings on H.R. 7852 and H.R. 8720 Before the House Comm. on Interstate and Foreign Commerce, 73d Cong., 2d Sess. 513-14 (1934).

4. 15 U.S.C. $\S \S 78 \mathrm{f}, \mathrm{j}, \mathrm{k}, 1, \mathrm{~s}(1964)$.

5. See Silver v. New York Stock Exch., 373 U.S. 341 (1963).

6. 1934 Act $\$ 2,15$ U.S.C. $\$ 78 b$ (1964).

7. The term "facility" when used with respect to an exchange includes its premises, tangible or intangible property whether on the premises or not, any right to the use of such premises or property or any service thereof for the purpose of effecting or reporting a transaction on an exchange (including, among other things, any system of communication to or from the exchange, by ticker or otherwise, maintained by or with the consent of the exchange), and any right of the exchange to the use of any property or service.

Id. \$ 3(a)(2), 15 U.S.C. \$ 78c(a) (2) (1964).

8. Id. $\$ 5,15$ U.S.C. $\$ 78 \mathrm{e}$ (1964).

9. Id. $\S 6,15$ U.S.C. $\S 78 f$ (1964). 
an agreement to enforce compliance by excliange members ${ }^{10}$ with the provisions of the Act and the rules formulated pursuant to it. ${ }^{11}$ Registration is not permitted nor may it continue unless the rules of the exchange "mclude provisions for the expulsion, suspension or disciplining of a member for conduct or proceeding inconsistent with just and equitable primciples of trade. . . "12 Finally if the Commission finds that the rules of an applicant exchange are "just and adequate to insure fair dealing and to protect investors,"13 it may be registered.

The statutory scheme ${ }^{14}$ is further einbellished by sections 11 and 19 of the 1934 Act. Section 11(a) permits the Commission to regulate floor trading by members on their own behalf. ${ }^{15}$ The Coinmis-
10. The term "member" when used with respect to an exchange means any person who is permitted either to effect transactions on the exchange without the services of another person acting as broker, or to make use of the facili- ties of an exchange for transactions thereon without payment of a cominission or fee or with the payment of a commission or fee which is less than that charged the general public, and includes any firm transacting a business as broker or dealer of which a member is a partner, and any partner of any such firm.

Id. $\$ 3(\mathrm{a})(3), 15$ U.S.C. $\$ 78 \mathrm{c}(\mathrm{a})(3)$ (1964).

11. Id. $\$ 6(\mathrm{~b}), 15$ U.S.C. $\$ 78 \mathrm{f}(\mathrm{b})(1964)$.

12. Id., 15 U.S.C. $\$ 78 \mathrm{f}(\mathrm{b})(1964)$.

13. Id. $\$ 6(d), 15$ U.S.C. $\$ 78 f(d)(1964)$.

14. A somewhat similar pattern of self-regulation is established for brokerdealers in the over-the-counter markets. See generally id. \& 15, 15 U.S.C. $\$ 780$ (1964). The only organization which has registered to date is the National Association of Securities Dealers, Inc. (NASD). This organization, like the exchanges, has the statutory responsibility to police its members with a view to protection of investors and to preserve the fairness and orderliness of the markets. The basic differences between the two statutory schemes are: First, the NASD disciplinary proceedings are reviewable by the Commission; second, the exchanges, unlike the NASD, may fix reasonable rates of commission. On October 22, 1970, the Commission in its statement concerning the NYSE commission rate proposal stated that it "is of the opinion that fixed charges for portions of orders in excess of $\$ 100,000$ are neither necessary nor appropriate." SEC, Securities Exchange Act Release No. 9007, at 2 (Oct. 22, 1970). On February 11, 1971, the Comunission stated to the NYSE that "in light of substantial changes in trading patterns . . . and to gain further experience with competitive rates, it wonld not object if [the NYSE] provided for competitive rates on portions of orders above a level higher than the $\$ 100,000$ figure . . . but that the point at which competitive rates are to commence should not exceed $\$ 500,000$." SEC Securities Exchange Act Release No. 9079, at 1 (Feb. 11, 1971). Third, the NASD, under section 15A of the 1934 Act [15 U.S.C. \& 780-3(a) (1964)], must be open to all qualified broker-dealers, but the exclianges presently have a limited membership; the Commission requested that the NYSE submit a plan for non-member broker-dealer access to Exchange facilities by no later than June 30, 1971 [SEC, Release No. 9007, supra at 3]; fourth, speciahists have specific duties under section $11 \mathrm{~b}$ [15 U.S.C. $78 \mathrm{k}(\mathrm{b})$ (1964)] and rule 11b-1 [17 C.F.R. \& 240.11b-1 (1970)], unlike over-the-counter market makers; fifth, NASD rnle proposals, unlike exchange rules, except those dealing with the specialist, may be formally "disapproved" by the Commission in advance of their effective date; and sixth, the Commission has broader powers to alter or supplement exchange rules than does the NASD. See generally Lowenfels, Private Enforcement in the Over-the-Counter Securities Markets: Implied Liabilities Based on NASD Rulk's, 51 CorNexx L.Q. 633 (1966).

15. 1934 Act $\S 11(\mathrm{a}), 15$ U.S.C. $\S 78 \mathrm{k}$ (a) (1964). 
sion has implemented this section by requiring exchanges to file plans governing floor trading for approval by the Commission. ${ }^{16}$ Section 11(b) permits the Commission to pass rules regulating the conduct of specialists. ${ }^{17}$ This section has also been implemented by Commission rule 11b-1 which requires the NYSE and American Stock Exchange (Amex) to pass specified rules regulating certam activities of the specialists. ${ }^{18}$ Section 19(a)(1) authorizes the Commission to suspend an exchange for a period not exceeding twelve months or to withdraw the registration of an excliange which it finds has violated the 1934 Act or any rules thereunder, or "has failed to enforce, so far as is within its power, compliance therewith by a member or by an issuer of a security registered thereon." 19 Section 19(a)(3) authorizes the Commission to suspend for a period of up to twelve months or to expel from an exchange a member or officer whom the Commission finds has violated any provision of the 1934 Act or Commission rules thereunder. ${ }^{20}$ Fimally, section 19 (b) permits the Commission to alter or supplement the rules of exchanges im twelve designated areas and in other areas regarding "similar matters."21

In short, the exchanges are required to formulate and enforce rules and to police their members for the purpose of preserving honest, or-

16. 17 C.F.R. \& 240.11a-1 (1970).

17. 1934 Act $\$ 11(b), 15$ U.S.C. $\$ 78 \mathrm{k}(\mathrm{b})$ (1964).

18. 17 C.F.R. $\& 240.11 b-1$ (1970). For discussion of rule $11 b-1$ see text accompanying notes 72-78 infra.

19. 1934 Act \& 19(a)(1), 15 U.S.C. \& 78s(a)(1) (1964). See San Francisco Mining Exch., SEC Securities Exchange Act Release No. 7106 (July 31, 1963).

20. 1934 Act $\$ 19$ (a)(3), 15 U.S.C. \$ 78s(a)(3) (1964).

21. The Commission is further authorized:

[T]o alter or supplement the rules of such exchange (insofar as necessary or appropriate to effect such changes) in respect of such matters as (1) safeguards in respect of the financial responsibility of meinbers and adequate provision against the evasion of financial responsibility through the use of corporate forms or special partnerships; (2) the limitation or prohibition of the registration or trading in any security within a specified period after the issuanee or primary distribution thereof; (3) the listing or striking froin listing of any security; (4) hours of trading; (5) the inanner, method, and place of soliciting business; (6) fictitious or numbered accounts; (7) the time and inethod of making settlements, payments, and deliveries and of closing accounts; (8) the reporting of transactions on the exchange and upon tickers maintained by or with the consent of the excliange, including the method of reporting short sales, stopped sales, sales of securities of issuers in default, bankruptcy or receivership, and sales involving other special circunstances; (9) the fixing of reasonable rates of commission, interest, listing, and other charges; (10) minimum units of trading; (11) odd-lot purchases and sales; (12) minimum deposits on margin accounts; and (13) similar inatters.

Id. $\S 19(\mathrm{~b}), 15$ U.S.C. $\S 78 \mathrm{~s}(\mathrm{~b})$ (1964). For a general discussion of the Commission's power with respect to proposed exchange rules, see Wolfson \& Russo, The Stock Exchange Specialist: An Economic and Legal Analysis, 1970 DURE L.J. 707, 722 n.63. 
derly and fair markets. ${ }^{22}$ In the absence of vigorous self-regulation, however, the structure will collapse and direct governmental intervention may be required. ${ }^{23}$

22. The House Report on the role of exchanges under the 1934 Act stated as follows:

The bill proceeds on the theory that the exchanges are public institutions which the public is invited to use for the purchase and sale of securities listed thereon, and are not private clubs to be conducted only in accordance with the interests of their members. The great exchanges of this country upon which inillions of dollars of securities are sold are affected witl a pubhic interest in the same degree as any other great utility. The Coinmission is empowered, if the rules of the exchange in any important inatter are not appropriate for the protection of investors or appropriate to insure fair dealing, to order such changes in the rules after due notice and hearings as it inay deem necessary. The exchanges may alter their rules if more effective means are discovered to neet the same or new problems. Although a wide measure of initiative and responsibility is left with the exchanges, reserved control is in the Commission if the exchanges do not meet their responsibility. It is hoped that the effect of the bill will be to give to the well-managed exchanges that power necessary to enable thein to effect themselves needed reforms and that the occasion for direct action by the Commission will not arise.

H.R. ReP. No. 1383, 73d Cong., 2d Sess. 15 (1934).

23. There are six major arguments in favor of self-regulation: First, it results in less need for an expanded governmental bureaucracy; second, it is less cumbersoine than a governmental bureaucracy; third, it is more practical and commonsensical; fourth, it is psychologically more acceptable to the industry; fifth, it directly places industry in the regulatory process; and sixth, it facilitates the development of ethical standards.

The arguments against self-regulation may be summarized as follows: First, businessinen will be reluctant to regulate their own conduct; as a corollary of this the more energetic staff personnel of exchanges will be discouraged by the member firms who employ them and pay the bills. Second, self-regulation results in a large professional bureaucracy which may be inore costly than a governinent staff; and third, self-regulation reqnires a Commission bureaucracy to oversee the selfregulators; this results in duplication of effort and conflicting jurisdictions. Sec Jennings, Self-Regulation in the Securities Industry: The Role of the Securities and Exchange Commission, 29 LAW \& CoNTEMP. ProB., 662 (1964).

Commenting on the role of exchanges, the Snpreme Court noted:

It was, therefore, the combination of the enormous growth in the power and impact of exchanges in our economy and their inability and unwillingness to curb abuses which had increasingly grave implications because of this growth, that moved Congress to enact the Securities Exchange Act of 1934. . . The pattern of governmental entry, however, was by no means one of total displacement of the exchanges' traditional process of self-regulation. The intention was rather,.... one of "letting the exchanges take the leadership with Government playing a residual role. Governinent would keep the shotgun, so to speak, behind the door, loaded, well oiled, cleaned, ready for use but with the lope it would never have to be used . . . ."

Silver v. New York Stock Excl., 373 U.S. 341, 351-52 (1963) (citations omitted). Recently the system of self-regulation has come under great stress and criticism due to the widespread failure and bankruptcy of many inember firms of the NYSE. Since January 1, 1970, five firms transferred their bookkeeping chores to other finns, 16 merged or sold out, and eight firms terminated business. NYSE, Special Membership Bull., Oct., 1970, at 1. The NYSE, in response to this criticisin, issued a special bullctin called Report on Sclf-Regulation to defend its efforts during these trying years of crisis. Id. This report states that "what precipitated this three-year crisis period was the fact that in late 1967 and in 1968 the most active securities markets in history 
Another remedy for the failure of a self-regulatory system to adequately attain its purposes would be a private cause of action against broker-dealers for violations of stock exchange rules. ${ }^{24}$ The existence

overwhelmed the industry's paperwork processing capacity." Id. (emphasis in original). After recounting the steps the Exchange had taken to alleviate the situation, the Bulletin concluded that in the case of three najor member organizations (DempseyTegeler, McDonnell \& Co. and Blair \& Co.) the Exchange found itself facing situations where normal apphication of rules resulting in the suspension of business due to violation of the net capital rules could have led to losses for thousands of customers. Id. at 2. The Exchange stated that immediate "suspension would have emptied these firms of clerical staff,. . . prompted a run by customers... and not have allowed orderly liquidation ...."Id. at 2 (emphasis in original). However, the question of whether such an approach will subject the Exchange or its members to successful civil hability suits is a serious question. Markizon, Net Capital Standards, 1970 Rev. Sec. Reg. 883.

In response to the financial crises in the securities industry, the Securities Investor Protection Act-which established insurance of customers of broker-dealers for up to 50,000 dollars of securities and 20,000 dollars in cash-was enacted on December 30, 1970. Pub. L. No. 91-598, 84 Stat. 1636.

That act includes three provisions on civil hability:

No self-regulatory organization shall have any liability to any person for any action taken or omitted in good faith pursuant to section $5(a)(1)$. Pub. L. No. 91-598, \& 9(b), 84 Stat. 1637.

(c) Liability of Members of SIPC. Except for such assessinents as may be made upon such member pursuant to the provisions of section 4 , no member of SIPC [Securities Investors Protection Corp.] shall have any liability under this Act as a member of SIPC for, or in connection with any act or omission of any other broker or dealer whether in connection with the conduct of the business or affairs of such broker or dealer or otherwise and, without limiting the generality of the foregoing, no meinber shall have any hability for or in respect of any indebtedness or other liability of SIPC. (d) Liability of SIPC and Directors-Neither SIPC nor any of its Directors shall have any hability to any person for any action taken or omitted in good faith under or in connection with any matter contemplated by this Act. Id. $\S 11$ (c) \& (d), 84 Stat. 1637.

The clear intent not to insulate members from impled civil liability as members of exchanges or the NASD is set forth in the Senate report which states: "It is not intended to exculpate members from habilities they may have as members of a selfregulatory organization or otherwise." SENATE COMM. ON BANKING AND CURRENCY, RePort ON Securities Investor Protection CorP., S. ReP. No. 91-1218, 91st Cong., 2d Sess. 15 (1970). Section 11(c) was primarily designed to insulate one member from the assessment of another nember. Indeed in an earher draft of what is now section 11(c) the phrase "no member of SIPC shall have any liability . . . as a member of SIPC" read "no member ... shall have any liability ... whether as a member of [SIPC], a member of a self-regulatory organization, or otherwise . . .." The deletion in the final Act of references to status as a nember of a self-regulatory organization emphasizes the above quoted Senate report. See Hearings on H.R. 13308, H.R. 17585, H.R. 18081, H.R. 18109 and H.R. 18458 Before the Subcomm. on Commerce and Finance of the House Comm. On Interstate and Foreign Commerce, 91st Cong., 2d Sess. 182 (1970). The equally clear intent not to insulate exchanges or the NASD froin civil liability except for action taken or omitted in good faith pursuant to section 5(a)(1) (which involves applying to a court to appoint a trustee for a bankrupt or financially troubled broker-dealer) is also articnlated in the Senate report which states that this sub-section is intended "only to relate to this Act and does not alter any liability of self-regulatory organizations which may already exist." S. REP. No. 91-1218, supra at 15 .

24. Instead of an action for damages an aggrieved party might wish to arbitrate 
and extent of broker-dealer hability is presently uncertain, however, simce it involves a relatively new area of the law. This Article examines the scant guidance provided by existing case law and suggests a test which the courts should apply in determining when the imposition of civil hability for violation of stock exchange rules would be appropriate.

\section{THE CASE LAW}

Colonial Realty Corp. v. Bache \& Co. ${ }^{25}$ first suggested that a meinber of a national stock exchange could be civilly liable for a violation of certain exchange rules:

A particular stock exchange rule could thus play an integral part in SEC regulations notwithstanding the Commission's decision to take a back-seat role in its promulgation and enforcement, and we would not wish to say that such a rule could not provide the basis for implying a private right of action.

his dispute with a member firm. The NYSE has arbitration facilities in which nonmembers may submit controversies with members for arbitration. See NYSE Const. art. VIII. Similar arbitration facilities are provided for by the NASD. Lowenfels sets forth the reasons why a plaintiff might prefer to bring an action in a federal court rather than utilizing arbitration facilities:

[First], because of the provision for nationwide service of process in Section 27 of the 1934 Act, the plamtiff's task of establishing jurisdiction and the proper venue may be an easier one. Second, a court possesses sweeping remedial powers which excliange arbitrators lack; . . . . Third, excliange arbitration offers the plaintiff nothing comparable to the rules of discovery provided by the Federal Rules of Civil Procedure. . . . Fourth, a plaintiff in court participates in the selection of those who will decide his case, and the jury, once chosen, will consist of people from widely scattered backgrounds and experiences. ... . Again, a plaintiff in court has the right of appeal; in exchange arbitration the decision of the arbitrators is conclusive.

Lowenfels, Implied Liabilities Based Upon Stock Exchange Rules, 66 Colum. L. Rev. 12, 29-30 (1966) (footnotes omitted). Arbitration should be considered an alternative to the federal courts and not be used as a reason to deny access to those courts. The Supreme Court lias lield that an agreement to arbitrate made in advance of a dispute arising under the Federal securities law is unenforceable if a public customer who is a party to that agreement wishes to use the federal courts. Wilko v. Swann, 346 U.S. 427 (1953).

25. 358 F.2d 178 (2d Cir.), cert. denied, 385 U.S. 817 (1966). In Colonial the plaintiff claimed that defendant, Bache, a NYSE member, breached an oral agreement by requiring margin in excess of the mimimum requirements of the NYSE and that as a result of Baclie's demands it suffered losses "running into millions of dollars and soine $\$ 100,000$ in commissions which Bache had collected." 358 F.2d at 179 (footnote omitted). Under the NYSE Constitntion a meinber who is found guilty of "conduct or proceeding inconsistent with just and equitable principles of trade may . . . be suspended or expelled." NYSE Const., art. XIV \& 6. Plaintiff believed that the breach of the oral agreement violated such "just and equitable principles of trade" which were referred to not only in the NYSE Constitution but also in sections $6(\mathrm{~b})$ and $15 \mathrm{~A}(\mathrm{~b})(7)$ of the 1934 Act [15 U.S.C. $\S 78 f(b)$ (1964); id. $\S 780-3(b)(8)]$, the NASD By-Laws, art. I, $\S 2$ (a) and the Rules of Fair Practice of the NASD, art. III, $\$ 1$. 
What emerges is that whether the courts are to imply federal civil liability for violation of exchange or dealer association rules by a member cannot be determined on the simplistic all-or-nothing basis urged by the two parties; rather the court must look to the nature of the particular rule and its place in the regulatory scheme, with the party urging the implication of a federal liability carrying a considerably heavier burden of persuasion than when the violation is of the statute or an SEC regulation . . . . ${ }^{26}$

The Colonial decision opened an entirely new area of securities law. The primary question presented by the landmark opinion was whether civil liability existed for violation of only a few stock exchange rules, or would be imposed with respect to violation of a relatively broad spectrum of exchange rules. The sparse case law following Colonial does not fully clarify this issue and Colonial and the other cases raise the additional questions of subject matter jurisdiction, the appropriate standard of care, the need for consistency between exchange rules and state and federal law, and whether the imposition of civil hability for violation of exchange rules violates the due process clause of the sixth or fourteenth amendinents. These questions are discussed in the following four subsections.

\section{A. Subject Matter Jurisdiction}

The primary jurisdictional issue which has arisen in private actions resting on violation of stock exchange rules is whether the federal courts have exclusive jurisdiction. Section 27 of the 1934 Act provides:

The district courts of the Umited States . . . shall have exclusive jurisdiction of violations of this title or the rules and regulations thereunder, and of all suits in equity and actions at law brought to enforce any liability or duty created by this title or the rules and regulations thereunder . . ..27

The Seventh Circuit has held that a stock exchange rule promulgated in accordance with sections 6 and 19 of the 1934 Act imposes a "duty created by this chapter" even if the rule is not in itself a rule

26. 358 F.2d at 182 (footnote omitted). The court found that plaintiff had not carried his burden of persuasion. Id. at 183. In Baird v. Franklin, 141 F.2d 238 (2d Cir.), cert. denied, 323 U.S. 737 (1944), it stated that an exchange could be liable for not enforcing rules adopted pursuant to section 6 of the 1934 Act [15 U.S.C. $\$ 78 f$ (1964)]. For a discussion of section 6(b), see text accoinpanying note 11 \& 12 supra. 1934 Act $\$ 6(b), 15$ U.S.C. \$ 78f(b) (1964). Pettit v. American Stock Exch., 217 F. Supp. 21 (S.D.N.Y. 1963), held that an exchange may be liable not only where it knew of a violation of certain section $6(\mathrm{~b})$ rules and did not act to prevent plaintiff's danage but also where it should have known of the violation. This area of exchange hability is particularly important during times of financial pressures on the exchange community and it is the exchange's responsibility to be aware of financial problems of its nember firms so as to help prevent damage to those who deal with these inembers.

27. 1934 Act $\$ 27,15$ U.S.C. $\$ 78$ aa (1964). 
"thereunder."28 Such an interpretation has been termed a "stretch of the language" in that it requires reading the words "created by" to mean "having its ultimate origin in." ${ }^{29}$ Moreover, exclusive federal court jurisdiction would strip a state court of the power to adjudicate controversies raised by violation of stock exchange rules even though all the parties were citizens of that state. ${ }^{30}$

However, the alternative theory of jurisdiction which has arisen is also troublesome. The Second Circuit has indicated in dicta that violation of a stock exchange rule by a member may be considered as "arising under" the Exchange Act and, therefore, federal courts would have concurrent jurisdiction with state courts. ${ }^{31}$ In the first place, it is not clear that such an interpretation of "arising under" is any less strained than the Seventh Circuit's reading of "created by." Moreover, although a member's hability for violation of a stock exchange rule is created by implication, it is so closely related to the purpose of the

28. Buttrey v. Merrill Lynch, Pierce, Fenner \& Smith, Inc., 410 F.2d 135, 142 (7th Cir.), cert. denied, 396 U.S. 838 (1969); see Lowenfels, supra note 24, at 18-19. See also Kroese v. New York Stock Exch., 227 F. Supp. 519 (S.D.N.Y. 1964).

29. Note, Private Actions as a Remedy for Violations of Stock Exchange Rules, 83 HARV. L. REV. 825, 834 (1970).

30. Colonial Realty Corp. v. Bache \& Co., 358 F.2d 178, 183 (2d Cir.), cert. denied, 385 U.S. 817 (1966).

31. 358 F.2d at 182; see 28 U.S.C. $\$ \$ 1331,1337$ (1964). A somewhat rclated issue is whether a state court has jurisdiction to adjudicate a defense resting on violation of a stock exchange rule. In Williams v. Sterling Oil, $-\mathrm{Del} \mathrm{Ch}$. 267 A.2d 630 (Ch. 1970), the court held that as long as contested proxies are in comphiance with Delaware law, NASD regulations contrary to Delaware law will not be enforced. The court relied heavily upon Investment Assoc. v. Standard Power \& Light Corp., 29 Del. Ch. 225, 48 A.2d 501 (Ch. 1946), which stressed that a state court has no jurisdiction over a cause of action based ou a violation of the 1934 Act. The court in Investment Associates stated that "qnestions concerning the admistration of the salutary act" should be left to the federal courts. Id. at $240,48 \mathrm{~A} .2 \mathrm{~d}$ at 509 . In Investment Associates the defendant raised the violation of section 14 of the 1934 Act [15 U.S.C. $\$ 78 n$ (1964)] as an affirmative defense. The court reasoned: "The fact that the violation is used as a defense in the present action in the sense that it is sought to be employed as a basis for rejecting a particular proxy cannot and does not obscure the fact that this court would be assuming jurisdiction to enforce the Act contrary to Section 27." Id. at 239, 48 A.2d at 509. The Williams court followed the Investment Associates case in that the defendant in Williams also sought to use a violation of the NASD proxy rules as a defense. A week after Williams was decided, the Seventh Circuit, in Aetna State Bank v. Altheimer, 430 F.2d 750 (7th Cir. 1970), took the position that in a state court action section 27 of the 1934 Act [15 U.S.C. \& 78aa (1964)] did not preclude the use of a violation of that Act as an affirmative defense. The court quoted Professor Loss as follows: "[N]othing in [Section 27] prevents the state court froin considering questions .... which are introduced by way of defense, and failure to do so would violate the supreniacy clause." $430 \mathrm{~F} .2 \mathrm{~d}$ at 754, citing $2 \mathrm{~L}$. Loss, SecuRITIEs Regulation 977, (2d ed. 1961). Indeed, Loss disagrees exphcitly with Investment Associates: "[T]he Delaware courts . . . were so impressed with the "exclusive jurisdiction' phrase in Section 27 of the Exchange Act that they failed to take into account the basic distimction between a federal action .... and a federal question raised by way of defense." 2 L. Loss, supra at 979. 
1934 Act that it would be anomalous to hold that such liability is not "created by" the Act. Exclusive federal jurisdiction would also have the effect of a more uniform interpretation of exchange rules. More pointedly, if the action is considered to arise under the 1934 Act, it is also "created by" that Act since in either case the genesis of the action is found in the 1934 Act. $^{32}$ This conclusion is clearly the most sensible interpretation. ${ }^{33}$ Finally, the test for liability proposed in part II of this Article-which is based partially on the existing case law-indicates the need for a close connection between a particular provision of the 1934 Act and the exchange rule at issue before liability for violation of that rule is proper, a test which, therefore, emphasizes the appropriateness of using section 27 of the 1934 Act as the statutory basis for subject matter jurisdiction.

\section{B. The "Protection of Investors" Rule and the Standard of Care}

One of the most important cases which followed Colonial was Buttrey v. Merrill Lynch, Pierce, Fenner \& Smith ${ }^{34}$ in which a trustee in bankruptcy founded a cause of action against a New York Stock Exchange member on the ground that the meinber had violated the socalled "know your customer" rule ${ }^{35}$ of the NYSE. The trustee al-

32. See Romero v. International Terminal Operating Co., 358 U.S. 354, 393 (1959).

33. See 2 L. Loss, supra note 31 , at $975-79$.

34. 410 F.2d 135 (7th Cir.), cert. denied, 396 U.S. 838 (1969).

35. NYSE Rule 405 provides:

Every member organization is required through a general partner, a principal executive officer or a person or persons designated under the provisions of Rule $342(b)(1) \ldots$ to . . . [u]se due diligence to learn the essential facts relative to every customer, every order, every cash or margin account accepted or carried by such organization and every person holding power of attorney over any account accepted or carried by such organization . . . .

In Hecht v. Harris, Upham \& Co., 430 F.2d 1202 (9th Cir. 1970), the court considercd the NASD "suitability" rule [NASD Const. art. III, $\$ 2$ 2] which is the equivalent to NYSE Rule 405. The court affirmed the lower court opinion that plaintiff was estopped on other grounds from claiming defendant's bability under the rule and therefore never decided if the NASD "suitability" rule could give rise to civil liability.

The lower court had stated in dictum concerning the NASD suitability rule, inter alia: "On this point we merely note that the Security Acts, as applicable to this case, are essentially directed at fraud-not against mere negligence or errors of judgment on the part of the broker." Hecht v. Harris, Uphain \& Co., 283 F. Supp. 417, 430 (N.D. Cal. 1968) (empliasis in original). This reasoning was used by the district court in Mercury Inv. Co. v. A.G. Edwards \& Sons, 295 F. Supp. 1160 (S.D. Tex. 1969). The court concluded that the NASD suitability rule seeks "to regulate a much broader spectrum of broker activities than is envisioned by the security regulations. Thus a violation of this N.A.S.D. rule per se does not give rise to fcderal civil liability under the Securities Act." Id. at 1163. Subsequent to the Mercury decision the Court of Appeals for the Seventh Circuit in Avern Trust v. Clarke, 415 F.2d 1238 (7th Cir. 1969), disagreed with this proposition citing its previous opinion in Buttrey (which was also decided subsequent to Mercury). 
leged defendant's knowledge that the bankrupt was using fraudulently converted property in security transactions with defendant. In affirming the district court's denial of defendant's motion for summary judgInent, the Seventh Circuit stated:

The touchstone for determining whether or not the violation of a particular rule is actionable should properly depend upon its design "for the direct protection of investors" .... Here one of the functions of Rule 405 is to protect the public, so that permitting a private action for its violation is entirely consistent with the purposes of the statute.

Such a breach of fair practices undermines the protection of investors and surely "play[s] an integral part in SEC regulation" of Exchanges and their members. ${ }^{36}$

The Buttrey court, in stating that the rule in question was "for the direct protection of investors", may have given the rule an interpretation which contradicts its actual intended ineaning. The Special Study of the SEC approximately seven years earlier had stated that Rule 405 was intended primarily but not solely for protection of the member and not for the protection of the general public. ${ }^{37}$ Had the court been interpreting a statute instead of an NYSE rule perhaps it would have given weight to the congressional intent behind enactment of the rule. An interesting question regarding Buttrey is whether the court would have reached the opposite conclusion had the contrary NYSE intent been explicitly written into the rule. ${ }^{38}$ In any event, the implication of Buttrey was that the area of civil liability for violation of a stock exchange rule was extremely broad. The "protection of the investor" test of determining when to impose civil liability could be satisfied by almost every stock exchange rule. ${ }^{39}$

36. $410 \mathrm{~F} .2 \mathrm{~d}$ at 142.

37. SEC, Report of Special Study of Securities Markets of the Securittes and Exchange Commission, H.R. Doc. No. 95, 88th Cong., 1st Sess., pt. 1, at 316 (1963):

In the study's public hearings, President Funston of the Exchange expressed the opinion that the "know your customer" rule was primarily designed to protect member firms against irresponsible customers, and the past application of the rule in exchange disciplinary proceedings confirns the view that it has generally been restricted to such use. However, the inspection program instituted by the exchange in 1962, discussed below in subsection (b), imdicates that the rule will apparently also be interpreted to impose an obligation on exchange members to prevent their salesmen from recommending unsuitable securities to their customers.

38. For a discussion of negation of liability see Shipman, Two Current Questions Concerning Implied Rights of Action Under the Exchange Act: Authority of the Administrative Agency to Negate; Existence for Violation of Self-Regulatory Requirements, 17 W. RES. L. REV. 925 (1966).

39. The "protection of the investor" test was emphasized by Lowenfels, supra note 24, at 12. See note 70 infra. See generally Allen, Liability Under the Securities Exchange Act for Violations of Stock Exchange Rules, 25 Bus. LAw. 1493 (1970). 
Another problem addressed by Buttrey was that of determining the standard of care to be imposed upon broker-dealers. The court pointed out that "[a]lthough mere errors of judgment ... might not support a federal cause of action, the facts alleged here are tantamount to fraud on the bankrupt's customers, thus giving rise to a private civil damage action." 10 This language was considerably expanded in Aetna Casualty \& Surety Co. v. Paine, Webber, Jackson \& Curtis, ${ }^{41}$ where the federal district court cited Buttrey as standing for the proposition that: "If any area of mnalfeasance by a stockbroker is not actionable, it would appear at least to comprehend the mere negligence alleged in this case." ${ }^{\prime 2}$ Aetna considered the same rule (NYSE Rule 405) that was involved in Buttrey but emphasized the failure to allege fraud rather than focusing on whether the rule was intended for the protection of investors and thus sufficient, if violated, to sustain a cause of action. ${ }^{43}$ The court also observed that Rule 405 was a vague ethical principle which under Colonial should not be the source of liability. ${ }^{44}$ By emphasizing the importance of the allegation of fraud in Buttrey, Aetna appears to have misinterpreted that case ${ }^{45}$ since the existence of fraud was held by Buttrey to be only sufficient and not necessary for the imposition of civil hability. ${ }^{46}$ Moreover, if fraud or something tantamount to fraud were necessary, the scope of civil liability for violation of a stock exchange rule would be very narrow. Indeed, if fraud is proven, there might well be hability under the federal securities laws themselvesespecially section 17 of the Securities Act of $1933^{47}$ and Commission rule $10 \mathrm{~b}-5^{48}$ or a state cause of action for deceit ${ }^{49}$ and hence there would be no necessity to rely upon violation of a stock exchange rule. Therefore, even if hability for such violations is recognized, the requirement that a finding of fraud is necessary might severely limit this remedy. In order to make civil hability an effective remedy, the courts should adopt the rule that mere negligence is sufficient to support a cause of action for violation of a stock exchange rule.

40. 410 F.2d at 143. 1970 ).

41. [1969-1970 Transfer Binder] CCH FED. SEC. L. REP. II 92,748 (N.D. Ill.

42. Id. at 99,274 .

43. Id. at $99,273-75$.

44. Id. at 99,275 .

45. The brief of Paine, Webber, Jackson \& Curtis stated: "There is no suggestion in Buttrey that, absent fraud, [the court] would have found federal jurisdiction for a broker's failure to make inquiry under Rule 405 . . ." Brief for Defendant at 20.

46. See note 40 supra and accompanying text.

47. 15 U.S.C. $\$ 77 q(1964)$.

48. 17 C.F.R. $\$ 240.10 b-5$ (1970).

49. See 2 L. Loss, supra note 31 , at 1623-31. 


\section{Consistency with State and Federal Law}

Section 6(c) of the 1934 Act requires that rules adopted by a stock exchange be "not inconsistent with . . . the apphicable laws of the State in which it is located." Since the Aetna court interpreted New York law to be that a "broker selling negotiable securities, is not required to investigate the title or ownership of such securities,"51 and since plaintiff in Aetna had alleged that NYSE Rule 405 would require such an investigation, ${ }^{52}$ the court held that plaintiff's interpretation would result in an inconsistency, and thus could not support a cause of action. ${ }^{53}$

The consistency between NYSE rules and federal law was considered in DeRenzis v. Levy. ${ }^{54}$ In that case plaintiff asserted that a private right of action existed for a violation of NYSE Rule 440A.11 which prohibits investment advisory fees "based upon the profits realized." The SEC filed an amicus curiae brief at the request of Judge Frankel which favored allowing a civil remedy:

[P]rivate enforcement based upon violations of some stock exchange rules is necessary 'to make effective the Congressional purpose' and

50. 1934 Act $\$ 6(c), 15$ U.S.C. $\$ 78 f(c)$ (1964).

51. [1969-1970 Transfer Binder] CCH FED. SEC. L. REP. \ 92,748, at 99,275.

52. Id. at 99,273 .

53. The court stated that the duty to ascertain title and ownership that the plaintiff sought to require of the defendant was "contrary to the policy of free negotiability of securities endorsed in blank that is now the rule in almost every state." Id. at 99,273-74 (footnote omitted).

The court neglected to mention section 8-318 of the Uniform Commercial Code which provides:

An agent or bailee who in good faith (including observance of reasonable coininercial standards if he is in the business of buying, selling or otherwise dealing with securities) has received securities and sold, pledged or dehivered them according to the instructions of his principal is not liable for conversion or for participation in breach of fiduciary duty although the principal had no right to dispose of thein.

UNIFORM COMMERCIAL CODE $\$ 8-318$. The commentary of Mr. Carlos Israels following this section in McKinney's Consolidated Laws of New York states: "If however the defendant is 'in the business of buying, selling or otherwise dealing with securities' he inust establish also his observance of 'reasonable commercial standards', including any applicable rule of the organized securities inarkets such as Rule 405 of the New York Stock Exchange ... N.Y. U.C.C. \$ 8-318 (McKinney 1964) (Preface Connmentary) (emphasis added). The author further states: "The jeopardy of the selling broker is broadened by the rules and practice of the organized markets which require that he "know his customer." Id. \$ 8-304 (Preface Commentary). Thus it appears that the Aetna court's view that a "broker selling negotiable securities is not required to investigate the title or ownership of such securities" may be incorrect under New York law if, in fact, NYSE Rule 405 would require such an investigation. Therefore it appears that the negotiable nature of a security does not in and of itself negate a duty to investigate. See generally C. Israels \& E. Guttman, Modern Securuties Transfers chs. XI, XII (1967).

54. 297 F. Supp. 998 (S.D.N.Y. 1969).

55. NYSE Rule 440A.11. 
to provide a 'necessary supplement' to the exchange's and the Commission's own action. In the absence of such remedies, the Commission might be required to promulgate rules of its own, covering areas already covered by exchange rules. Otherwise public investors would not be adequately protected. Denial of such remedies based upon a formalistic distinction between the exchange's rule and those of the Commission would be inconsistent with the statutory purpose. . . . Rule 440.A11 is clearly the type of exchange rule that should give rise to a private right of action. ${ }^{56}$

The court examined the legislative history of both the Investmerit Company $\mathrm{Act}^{57}$ and the Investment Advisers $\mathrm{Act}^{58}$ and noted that the precise provision in NYSE Rule 440A.11 had originally been in both Acts and had been intentionally deleted. ${ }^{59}$ The court then reasoned that if Congress had deliberately refused to enact the prohibition embodied in NYSE Rule 440A.11, a court could not circumvent the congressional intent by implying civil liability. ${ }^{60}$

\section{Civil Liability and Due Process of Law}

The DeRenzis case also raised the question of whether "the procedures whicl gave birth to exchange rules"-involving the lack of notice and opportunity for comment-in conjunction with the imposition of civil hability, violate the due process clause of the sixth or fourteenth amendments. ${ }^{61}$ Judge Frankel stated in dicta:

[e]ven public officials making 'egislative' enactments of any public consequence should be bound to at least minimal standards of notice and an opportunity for people affected to be 'heard' in some rudimentary way. . . . This is not a concern, of course, when the promulgating exchange itself is being called upon to obey or enforce its own rules and regulations. ... The problem becomes more troublesome, however, when it is proposed that such rules should de-

56. Brief for SEC as Amicus Curiae at 9-10 (citations omitted). The Commission's amicus curiae brief further stated:

In some areas the existence of a private right of action for damages might inhibit the self-regulatory body from promulgating new rules in areas beyond the Commission's own authority to do so. In others, the imposition of damages may actually impede rather than advance the self-regulatory purpose. Therefore, a careful examination must be made with respect to the particular rule to determine whether the implication of a private right of action would in fact further the overall objective of the federal securities law.

57. 15 U.S.C. $\$ \S 80 a-1$ et seq. (1964), as amended, (Supp. V, 1970).

58. Id.

59. 297 F. Supp. at 1003-04, citing United States v. Muniz, 374 U.S. 150, 156 (1963).

60. 297 F. Supp. at 1004.

61. Id. at 1001-02 n.5. It should be noted that while NYSE rules do not have to be submitted to a vote of the NYSE membership, a constitutional amendment would require a vote. NYSE Const. art. XX. 
fine valuable rights and costly liabilities for members of the exchange and people dealing with them. ${ }^{62}$

An analogous due process issue was squarely presented in Harwell $v$. Growth Programs, Inc. ${ }^{63}$ involving an NASD interpretation of its rules of fair practices. Plaintiffs were purchasers of mutual fund shares under a contract which included provisions limited by an NASD imterpretation promulgated subsequent to the contract. Plaintiffs sought a court order declaring the contract valid and enjoining the fund from breaching it by following the inconsistent interpretation. They contended that the promulgation of the interpretation without a rulemaking hearing violated their due process rights. Although the court noted that the NASD procedures left a "great deal to be desired" the court held that there was "no constitutional infirmity" and that the NASD interpretation "is clearly within the power granted the NASD by the Maloney Act; that it was issued pursuant to proper procedure; and that it is reasonable." $" 64$

It appears obvious, as Judge Frankel observed, that when the pro1nulgating self-regulatory group itself is being asked to obey its rules it must be bound by them regardless of weak standards of notice and hearing. ${ }^{65}$ However, the same is true for meinbers. Exchanges are by law the creatures of their members, and it is the members who have ultimate control over establishing the method of promulgation of rules and regulations. ${ }^{66}$ Therefore, members should not be perinitted to

62. 297 F. Supp. at 1001-02 n.5 (citations omitted). Judge Frankel in the $D e$ Renzis case raised an interesting question with respect to whether the "supplementary unaterial" which follows unany NYSE rules ought to be considered a true rule:

Assuming plaintiff's answer to the hard question whether stock excbange rules may ever give rise to rights like that asserted here, this could only be true if, at a minimun, the propositions in question were pronulgated, recorded, and known as rules-or, at least, something closely approximating rules. The motion papers lack any certam assurance on this score. And so, if the pertinent inaterials led in other respects to plaintiff's conclusion, this subject would require further exploration.

Id. at 1001 .

63. CCH Fed. SEC. L. Rep. \ 92,694, at 99,067 (W.D. Tex. 1970), appeal docketed, No. 30,501, 5th Cir.

64. Id. at 99,070-71. Apparently plaintiffs beheved they could not prevail on the theory that the stringent rule-making procedure set out in section 4 of the Administrative Procedure Act (APA) [5 U.S.C. \& 553 (1964)] was followed. Section 4 of the APA requires agencies in general to give notice and opportunity to comment on proposed rules. CCH FED. SEC. L. REP. If 92,694, at 99,070. The court cited section 551(1)(E) of the APA [5 U.S.C. $\$ 551(1)(E)$ (1964)], which excludes from its defiuntion of agency "agencies composed of representatives of the parties or of representatives or organizations of the parties to the disputes determined by them." CCH FED. SEC. L. REP. at 99,067-70. The court felt that the plaintiffs might have believed that the NASD is not an agency subject to section 4 of the Act.

65. See text accompanying note 62 supra.

66. See NYSE Const. arts. I, II, VII \& XX. 
have their procedural cake and eat it too. In other words, they cannot be permitted to adopt and continue methods of promulgating rules by which they are governed and, at the same time, negate their civil liability for violation of the rules because of the procedural weaknesses attending the methods of promulgation. ${ }^{67}$

Although it may be claimed that a non-member as in the Harwell situation has not agreed to accept all rules-present or future-simply by contracting with a member, the contention that the nonmember implicitly agrees to the NASD rules and interpretations by dealing with a member is equally plausible. ${ }^{68}$ In any event the rule in Harwell should apply a fortiori in a case where a member of either an exchange or the NASD is sued for violating a rule because the member as a condition to and by virtue of his membership, explicitly agreed to abide by the organization's rules. ${ }^{69}$ More to the point, even if the Harwell court had ruled in favor of the non-meinber, liability of members would clearly not be foreclosed on due process grounds.

II

\section{A PROPOSED TEST}

Since few cases have addressed the issue of implied civil libability under the 1934 Act for member violation of stock exchange rules, it is
67. See note 38 supra.
68. The SEC in its Amicus Curiae brief in Harwell stated:
[W]e submit that it would be wholly contrary to the regulatory aims of the Act for this court to hold that the NASD's interpretation of its rule is not applicable to the contracts here involved. If, as here, a member of the NASD enters into a relationship with a non-member, which relationship is contrary to "just and equitable principles of trade" because of its unfairness to numerous other investors, the non-member should not be permitted to prevent the NASD from terminating that relationship, otherwise the NASD will be un- able to perform the important functions intended by Congress for such an association.

Brief of the SEC as Amicus Curiae 25-26.

69. It may be argued that he never agreed to be civilly liable for a violation of the rule. NYSE listed companies also agree to abide by NYSE rules but it has been held that "a suit against a listed company or its officers based on violation of an Exchange nule" does not arise under federal law. O'Neill v. Maytag, 339 F.2d 764, 770 (2d Cir. 1964). However, even assuming the O'Neill case correct on this point, the status of the meinber is obviously more closely intertwined with the basic concept of self-regulation than is the status of histed companies. In addition, it should be noted that the O'Neill decision was based upon the argument that a listed company, unlike an exchange, is not under a federal duty to obey exchange rules. This rationale with respect to exchange nembers-who, under section 6 of the 1934 Act, do not have a specific duty to obey exchange rules-was in effect rejected by subsequent decisions. Buttrey v. Merrill Lynch, Pierce, Fenner \& Smith, Inc., 410 F.2d 135 (7th Cir.), cert. denied, 396 U.S. 838 (1969); Colonial Realty Corp. v. Bache \& Co., 358 F.2d 178 (2d Cir.), cert. denied, 385 U.S. 817 (1966). 
extremely difficult to predict the circumstances that will result in the imposition of liability. This part of the Article proposes a test. The first two subsections focus on the type of rule whose violation would warrant an imphed private action. The third subsection indicates the most appropriate standard of care. Finally, the fourth subsection i1lustrates a hypothetical application of the proposed test.

\section{A. Rules Explicitly Required or Permitted by the SEC}

The essential requirement of a test of civil hability is that the exchange rule in question reflect basic ethical or legal standards for the protection of investors which are manifested in the 1934 Act or the rules thereunder. These should be standards which are so important that the Commission would have to exercise its "reserved control" if the exchanges did not meet their responsibility. ${ }^{70}$ The most obvious category is coinprised of those rules which are required to be enacted by specific Commission rules and regulations as a "substitute for regulation by the SEC itself." T1 Typical examples are the specialist rules which the NSYE and Amex were required to pass by Commission rule $11 \mathrm{~b}-1 .^{72}$

70. It has often been correctly pointed out that exchange rules, in order to be a basis for hability, must have been enacted for the purpose of protecting investors. See Lowenfels, supra note 24. Such rules fulfill central purposes of the 1934 Act which requires exchanges to pass rules to protect investors. Private enforcement of such rules would help effectuate the congressional purpose and afford a uecessary supplement to exchange and Commission activities. Moreover, this requirement is in accord with the tort doctrine which requires a court to determine whether a statute or rule was designed to protect persons in plaintiff's category before finding impled civil liability for violation of the standards of conduct prescribed by the statute. RESTATEMENT (SECOND) OF TORTS $\S 286$ (1965). Unfortunately the standard of imvestor protection standing alone without adequate reference to specific provisious of the 1934 Act or rules thereunder is difficult to define with satisfactory precision. It is capable of being stretched to cover evcry suit because every violation of an exchange rule which is brought to trial will involve a plaintiff who has allegedly suffered harn. If in fact he can prove that the violation of the rule caused the harm, the court may be very ainenable to finding that since the plaintiff is an investor, the rulc in question was designed to protect him. It is therefore cssential, as illustrated in the text, to require reference to sections of the 1934 Act, rules thereunder, and legislative purpose, as objective evidence of required standards of conduct for the protection of investors to determine wliether violation of an exchange rule is actiouable.

71. Colomal Realty Corp. v. Bache \& Co., 358 F.2d 178, 182 (2d Cir.), cert. denied, 385 U.S. 817 (1966).

72. 17 C.F.R. $\$ 240.11$ b-1 (1970). This rule provides in part:

(a) (1) The rules of a natioual securities exchange may permit a inember of such exchange to register as a specialist and to act as a dealer. Any change in or addition to the rules of such exchange in the areas covered by paragraph (a)(2) of this rule made after this rule becomes applicable to such exchange shall be subject to the provisions of paragraph (a) (3) of this rule.

(2) The rules of a uational securities exchange permitting a member of such exchange to register as a specialist and to act as a dealer shall imclude:

(i) Adequate minimum capital requirements in view of the markets 
Section 11(b) of the 1934 Act empowers the Commission to pass comprehensive rules regulating the conduct of specialists ${ }^{73}$-members of exchanges who perform the essential task of making markets in particular stocks out of inventory thus helping to contribute to the depth and liquidity of the auction market. ${ }^{74}$ The Commission did not initially promulgate its own rules to regulate their conduct. Instead it reled upon exchange rules. However, in 1935 the Commission did suggest language of a particular rule which all exchanges with a specialist system adopted with varying formats to suit their particular needs. ${ }^{75}$ In 1963 the Commission's detailed Special Study of the securities markets analyzed the specialist system in depth and made certain recommendations for improvement. ${ }^{78}$ As a result of these studies, the Commission finally promulgated rule $11 \mathrm{~b}-1$ effective in $1965 .{ }^{77}$ The comprehensive scheme of regulation set forth in rule $11 b-1$ requires the NYSE and

for securities on such exchange;

(ii) Requirements, as a condition of a specialist's registration, that a specialist engage in a course of dealings for his own account to assist in the maintenance, so far as practicable, of a fair and orderly market, and that a finding by the exchange of any substantial or continued failure by a specialist to engage in such a course of dealings will result in the suspension or cancellation of such specialist's registration in one or more of the securities in which such specialist is registered;

(iii) Provisions restricting his dealings so far as practicable to those reasonably necessary to permit him to maintain a fair and orderly market or necessary to permit him to act as an odd-lot dealer;

(iv) Provisions stating the responsibilities of a specialist acting as a broker in stocks in which he is registered; and

(v) Procedures to provide for the effective and systematic surveillance of the activities of specialists.

73. 15 U.S.C. $\$ 78 \mathrm{k}(\mathrm{b})(1964)$.

74. The Specialist as a member of a stock exchange has two functions. He must execute orders which other nembers of an exchange may leave with him when the current market price is away from the price of the orders. By executing these orders on behalf of the other exchange members when the market price reaches the price stated on these orders, the specialist makes it possible for these meinbers to perform their business elsewhere on the Floor. In handling these orders, the specialist acts as broker or agent. In addition to the brokerage functions, however, he has historically had the additional function of acting as dealer or principal for his own account. Under current rules and regulations of the exchanges and the Securities and Exchange Coinmission, purchases and sales for his own account must be made, insofar as reasonably practicable, with a view to assuring a fair and orderly market in the stocks which he services. Moreover, whenever there are public buyers but no public sellers, or public sellers but no public buyers, he is expected, within reasonable limits, to buy or sell for his own account in order to decrease price differences between transactions and to add depth to the market. $\mathrm{He}$ performs both functions for a limited number of issues assigned to him by the stock exchange.

Wolfson \& Russo, supra note 21, at 707-08 (footnotes omitted).

75. Id. at 717-21. The rule was similar to section $11(\mathrm{~b})$ and prohibited dealer trades by specialists unless reasonably necessary to permit such specialists to maintain a fair and orderly market. Id. at 718 .

76. SEC, supra note 37 , pt. 2, at 57-171.

77. Wolfson \& Russo, supra note 21, at 721-26. 
Amex to pass rules which include adequate minimum capital requirements, requirements that a specialist engage in a course of dealing to help maintain a fair and orderly market, provisions restricting his dealings to those reasonably necessary to help maintain such a market, and certain other provisions. ${ }^{78}$ Similarly, under section 11 (a) of the $1934 \mathrm{Act}^{, 9}$ the Commission promulgated rule $11 \mathrm{a}-1$ which required exchanges to pass certain specified rules regulating floor trading by members for their own account. ${ }^{80}$

Other exainples are the net capital rules of exchanges: brokerdealers are subject to Commission rule 15c3-1 which imposes specified minimum net capital requirements as a condition to continuing in business. ${ }^{81}$ A section of this rule, however, provides that it shall not apply to members in good standing of the NYSE, Amex and certain other exchanges "whose rules, settled practices, and applicable regulatory procedures are deemed by the Commission to impose requirements [that are] more coinpreliensive . . . than the Commission rule." cases, the Commission has made a deliberate decision to require or permit the exchange to landle vital areas of regulatory concern while the Commission takes a "back-seat role." 83 Violation of exchange rules in these areas would provide a clear basis for implying a private right of action.

A recent decision of the Court of Appeals for the District of Columbia nay have the effect of enlarging the category of rules which should be explicitly traceable to Commission action. In Independent Broker Dealers Trade Ass'n v. SEC ${ }^{84}$ the issue was whether certain

78. 17 C.F.R. \& 240.11b-1 (1970). See Wolfson \& Russo, supra note 21, at 727-40. See note 72 supra.

79. 1934 Act $\$ 11$ (a), 15 U.S.C. \& 78k(a) (1964).

80. 17 C.F.R. \& 240.11a-1 (1970).

81. Id. § $240.15 \mathrm{c} 3-1$.

82. Id.

83. Colonial Realty Corp. v. Bache \& Co., 358 F.2d 178, 182 (2d Cir.), cert. denied, 385 U.S. 817 (1966). Of course, if the exchauges fail or are unable to regulato effectively, the Commission must exercise its own rule making prerogatives under sections $15(\mathrm{c})(3)$ and 19 (b) of the 1934 Act, 15 U.S.C. $\$ \S 78 \mathrm{~s}(\mathrm{~b})$ \& $780(3)$ (1964). For the text of section 19 (b) see note 21 supra. Another obvious category would be those exchange rules which have been directly "altered" or "supplemented" by formal order of the Commission under section 19(b). In such a case the exchange rule is a direct substitute for a Commission rule and refusal of a renedy based upon a technical differentiation between the exchange rules and rules of the Commission would be without logical basis. The only 19(b) proceeding to date involved the rejection of a proposed rule of the NYSE on the basis that it was contrary to the antitrust laws and injurious to regional stock exchanges. Rules of the New York Stock Exch., 10 S.E.C. 270 (1941). A number of exchange rules, however, have been adopted after suggestion by the Commission that it might consider formal section 19(b) proceedings. See rule 19b-1, 17 C.F.R. \$ $240.19 \mathrm{~b}-1$ (1970); SEC, Securities Exchange Act Release No. 34-7981, (Nov. 7, 1966); NYSE Rule 394(b).

84. CCH FED. SEC. L. REP. IT 92,963 (D.C. Cir. Mar. 4, 1971). 
Commission actions suggesting an exchange rule change amounted to a Commission order or action reviewable by a court of appropriate jurisdiction. In that case the court held that Commisision letters and suggestions to the NYSE, in the light of the particular factual setting, constituted 'agency action' within the meaning of the Administrative Procedure Act. ${ }^{85}$ The Court observed: "The fact that an agency has not issued a command does not mean that the step by which it initiated a procedure, or informal activity leading up to the exercise of its powers, may be relegated to the area of mere unreviewable 'suggestion.' "\$6 The court noted that the significant Commission involvement in the NYSE rule change "cannot be ignored as devoid of legal materiality."

\section{B. Rules Implicitly Traceable to Specific Statutory Provisions}

There are many other important exchange rules intended for the protection of investors which are not explicitly required or permitted by a formal Commission rule. However, the relevance of many of these to significant ethical and legal standards for the protection of investors may be traced to specific sections of the 1934 Act. A prime example is section $19(\mathrm{~b})^{88}$ which permits the Commission to alter or supplement exchange rules in specified areas. Many of these areas involve the relationships between member firms and public customers, and violation of exchange rules regulating such important subjects of investor concern slould invoke hability. ${ }^{89}$ Subsection (1) of section 19(b) refers to rules pertaining to the financial responsibihity of members, a subject of vital importance to the protection of public investors. ${ }^{90}$ Another subsection covers the "manner, method and place of soliciting business" - the crucial area of members' standards of conduct in soliciting the business of public customers. ${ }^{91}$ Another refer-

85. 5 U.S.C. $\$ \S 702,704$ (1964).

86. CCH FED. SEC. L. REP. $\int 92,963$, at 90,567.

87. Id. at 90,566 .

88. 1934 Act $\S 19(b), 15$ U.S.C. $\& 78 s(b)$ (1964). The Commission has stated that "it is clear that under the rules of law governing construction of statutes Section 19(b) should be construed broadly to accomphish its purposes." Rules of the New York Stock Exch., 10 S.E.C. 270, 293 (1941) (footuote omitted).

89. See Colonial Realty Corp. v. Bache \& Co., 358 F.2d 178, 182 (2d Cir.), cert. denied, 385 U.S. 817 (1966).

90. 15 U.S.C. \& 78s(b)(1) (1964). See, e.g., NYSE Rules 417-21. Most exchange rules such as these and others dealing with fimancial statements of member firms and reports of condition to the Exchange, customers, stockholders or lenders are vital rules within the meaning of investor protection and the purposes of section $19(\mathrm{~b})$.

91. 1934 Act $\$ 19$ (b) (5), 15 U.S.C. $\$ 78 \mathrm{~s}(\mathrm{~b})(5)$ (1964). See, e.g., NYSE Rules 471,472 and 473 which set forth certain requirements with respect to advertising, market letters, sales literature, radio, television and telephone reports. These and other rules which govern standards for soliciting business are important means to insure protection of investors within the meaning of the 1934 Act. See discussion of NYSE Rule 
ence is to "fictitious or numbered accounts" to prevent fraudulent or manipulative securities transactions through the use of dummy accounts. $^{92}$ The next subdivision refers to the time and method of making settlements, payments and deliveries and covers the subject matter of back office delays, operational deficiencies, failures to deliver and, in general, the need to assure honest and effective settlement and clearing meclianisms. ${ }^{93}$ Problems in this area grew to crisis proportions in 1967-68 and led the Commission to issue a release reiterating its opinion that brokers' failures to deliver could amount to fraud under the securities law. ${ }^{94}$ The next subsection deals with reporting transactions on exchanges. ${ }^{95}$ Accurate reporting of stock transactions is central to the maintenance of informed investors and material errors or omissions could lead to mistaken decisions and substantial losses. ${ }^{26}$ Subsection $11^{\text {o7 }}$ pertains to odd-lot purcliases and sales, including regulation of the important relationship between sinall investors and both the commission louse which takes their orders and the odd-lot firm whicl actually executes it on the floor of the excliange. Subsection $12^{98}$ refers to minimum deposits on margin accounts. The importance of proper maintenance and liandling of customers' margin accounts is obvious and violation of spe-

405 in text accompanying notes 35-38 supra.

The Commission las interpreted the phrase "manner, method, and place of soliciting business" as follows:

The NYSE asserts that ... Congress intended by this subdivision inerely to give the Commission power to deal with the overt conduct of exclianges and their members in "going out after business." By definition, argues the NYSE, "soliciting" carries with it ordinarily the connotation of "requesting something with some degree of earnestness." The courts, however, have held that soliciting may be practiced by means other than personal entreaty or use of words, that it requires no particular degree of importunity and that conduct intended or calculated to invite patronage or business may also amount to soliciting.

Rules of the New York Stock Exch., 10 S.E.C. 270, 295 (1941) (footnote omitted) (emphasis in original).

92. 1934 Act $\$ 19(b)(6), 15$ U.S.C. $\$ 78 s(b)(6)$ (1964). See, e.g., NYSE Rule 406 which provides that "[n]o member organization shall carry an account . . . in the name of a person other than that of the customer . . .."

93. 1934 Act $\S 19(b)(7), 15$ U.S.C. $\S 78 \mathrm{~s}(\mathrm{~b})(7)$ (1964). The NYSE las stated: "More than $90 \%$ of estimated potential costs of liquidating firms under the Exchange's Special Trust Fund stem from record-keeping problems." NYSE, supra noto 23, at 2. See, e.g., NYSE Rule 282, which refers to mandatory buy-ins.

94. SEC, Securities Exchange Act Release No. 8363 (July 29, 1968): "The Commission also wams broker-dealers that it is a violation of applicable anti-fraud provisions for a broker-dealer to accept or execute any order for the purchase or sale of a security or to induce or attempt to induce such purchase or sale, if he does not have the personnel and facilities to enable him to promptly execute and consummate all of his securities transactions."

95. 1934 Act $\$ 19(b)(8), 15$ U.S.C. $\$ 78 s(b)(8)(1964)$.

96. See NYSE Rule 128.

97. 1934 Act $\$ 19$ (b)(11), 15 U.S.C. $\$ 78 \mathrm{~s}(\mathrm{~b})(11)$ (1964). See generally NYSE Rules 94, 99, 100-02.

98. 1934 Act $\$ 19(b)(12), 15$ U.S.C. $\$ 78 s(b)(12)$ (1964). 
cific exchange rules dealing with this subject should be a source of civil liability. ${ }^{99}$ Generally, effective exchange rules in this area will lessen the risk of excess speculation with thinly margined accounts.

\section{The Standard of Care and Other Considerations}

Whether or not the rule which supports civil liability is explicitly required or permitted by the SEC, or traceable to specific provisions of the 1934 Act, it should be reasonably explicit. This requirement is a threshold condition of fairness and predictability which will prevent burdening the federal courts with a torrent of cases involving general rules concerning unethical behavior for which there are no guidelines in prior exchange or judicial decisions. ${ }^{100}$ However, where precedents exist, this problem is not present. Care must be taken to distinguish between such vague rules and rules which have been prescribed by Commission rules-such as the specialist and net capital rules. The latter rules require interpretation and analysis, but in view of their statutory sanction and the integral part they play in SEC regulation they should not be disregarded.

Fimally, it should also be noted that an exchange rule inust always pass the gauntlet of antitrust consideration. That is, if the rule is invalid under antitrust principles, the member may not be hable for violating it. ${ }^{101}$

Another question which must be decided is the degree of scienter on the part of a stock exchange member that will justify imposing liability-whether mere negligence is sufficient, or whether the member must have willfully violated the rule. ${ }^{102}$ Several reasons indicate that some degree of negligence should be sufficient to sustain liability. In the first place, in order to provide a basis for hability the rule at issue must be one which embodies important standards of the 1934 Act. ${ }^{103}$

99. See NYSE Rule 431 on margin requirements. It should be noted that the Colonial case did not deal with this rule but with an alleged oral agreement pertaining to it. See note 25 supra.

100. See Colonial Realty Corp. v. Bache \& Co.. 358 F.2d 178, 183 n.6 (2d Cir.), cert. denied, 385 U.S. 817 (1966).

101. A divided court in Thill Securities Corp. v. New York Stock Exch., 433 F.2d 264 (7th Cir. 1970), cert. denied, 39 U.S.L.W. 3424 (U.S. Mar. 29, 1971) (No. 1263), interpreted the 1934 Act as being subordinated to the antitrust laws. The Midwest Stock Exchange, as amicus curiae in Thill, has taken the position that this subordination "necessarily opens to antitrust attack many rules and regulations of every exchange .... Thus, the divided opinions in Thill open the way to private litigation of issues which the Congress placed in the hands of the SEC thirty-six years ago." Brief of the Midwest Stock Exchange as Amicus Curiae in Support of Petition for Rehearing in Banc at 4. Thill was remanded to the district court.

102. See notes $45-49$ supra and accompanying text.

103. See text accompanying notes 71-97 supra. 
Accordingly, the damage which results from violation of this type of rule has been, in effect, prescribed by the statute and rules thereunder. The tort doctrine which supports an action based on violation of a statute is a neghigence action. ${ }^{104}$ Additionally, the imposition of liability for neghigence will be an effective impetus for adequate self-regulation. Moreover, a requirement of willfulness may vitiate the importance of exchange rule violations as a separate basis for liability, since in many cases such a requirement would also imvolve hability under rule $10 \mathrm{~b}-5^{105}$ or section 17 of the Securities Act of $1933^{106}$ or liability for common law deceit ${ }^{107}$ Naturally the customary requirement of proximate cause will be necessary. However once it has been found that the exchange member has violated the rule, the burden to disprove causation should rest with the erring meinber who has violated his duty to obey exchange rules. ${ }^{108}$

\section{An Example}

The application of the proposed test can best be illustrated by an example. Suppose the following case: A speciahist unit has a stock called $X Y Z$, Inc. The stock opens at 35 dollars on September 12 and stays in the range of 35-45 dollars for six months. The specialist cultivates a close business relationship with Jones, the controlling stockholder of the $X Y Z$ company. The business relationship consists of extensive and numerous dealings by the two in businesses completely unrelated to that of $X Y Z$, Inc. Eventually the news breaks that the

104. See Restatement (SECOND) OF ToRTS \& 286 (1965).

105. 17 C.F.R. $\$ 240.10 \mathrm{~b}-5$ (1970).

106. 15 U.S.C. \& 77q (1964).

107. For a different view see Aetna Cas. \& Sur. Co. v. Paine, Webber, Jackson \& Curtis, [1969-1970 Transfer Binder] CCH FED. SEC. L. REP. If 92,748 (N.D. Ill. 1970). See text accompanying note 41-44 supra.

108. Iu Baird v. Franklin, 141 F.2d 238 (2d Cir.), cert. denied, 323 U.S. 737 (1944), the court held that in a suit against the NYSE the plaintiff had the burden of proving that the breach of the NYSE duty under the 1934 Act caused plaintiff's loss. In his dissent Judge Clark stated:

The writer hereof feels constrained to dissent from the ruling that the burden of the evidence as to damages remained with the plaintiffs throughout. . . . This would seem to follow because an investor not only is not iu a position to know the facts about an Exchange member, but normally relies upon the standing given him by his membership, particularly in view of the recent highly publicized statutory and other reforms of Exchange activities; whereas the Exchange itself has a complete machinery for keeping itself informed and for taking disciplinary proceedings against a member guilty of any impropriety. Any other rule seemingly imposes little responsibility upon the Exchange for carrying out the duty which we have found the Act to place upon it, and even provides an incentive, after the Exchange has become aware of a serious condition, for it to let matters drift, while it and its members having special knowledge protect theinselves just as they did here-a result which, to my mind, borders on the immoral, in that it encourages a fiduciary to safeguard its own private interests while it allows its beneficiaries to suffer.

141 F.2d at 246-47. 
company is, and always has been, in grave financial difficulty-a fact which was unknown to the specialist and was intentionally concealed from the public by Jones. The stock drops sharply to 15 dollars and stays at that level. Plaintiff is a stockholder who bought 1000 shares in September at 35 dollars and upon selling the stock when the news is announced, suffers a 20,000 dollar loss. He alleges that the specialist has violated NYSE Rule $401,{ }^{109}$ or $460.10,{ }^{110}$ or both, which he asserts prohibits business dealings of any kind between a specialist and any imsider of the issuer in whose stock he is a specialist, and that the specialist is therefore hable to him for his loss. The answer of the specialist is: Even if I admit that I violated any rule, which I deny, the violation can scarcely be deemed the proximate cause of the initial price range of 35-45 dollars and the drop to 15 dollars; nor was the violation the proximate cause of plaintiff's buying the stock or holding it; furthermore, the rules at issue are generalized ethical prescriptions which are too vague to support an action for civil hability.

On these facts plaintiff might lose since it nay be difficult for him to prove that the violation of these rules was the proximate cause of plaintiff's injury. Moreover, if the specialist has the burden of proving lack of proximate cause, which he probably does, this is a case where the specialist might carry his burden.

Now suppose an entirely different case where there was no bad news and the specialist was given secret loans by $X Y Z$, Inc. and options to sell its stock, and his wife had a secret short account im the stock. The stock declines from 35 dollars a share to 15 dollars a share. Under these circumstances, the specialist has violated a duty imposed by Commission rule $11-b-1^{111}$ as expressed in exchange Rules $104^{112}$ and

109. NYSE Rule 401 provides: "Every member, allied member and member organization shall at all times adhere to the principles of good business practice in the conduct of his or its business affairs."

110. NYSE Rule 460.10 provides:

No specialist should be in a control relationship with any company in whose stock lie is registered. This applies not only with respect to the ownership of $10 \%$ or more of the stock im such a company, but also to business transactions of any kind with such companies; for example, loans, etc. A specialist must not accept a finder's fee from a company in whose stock lie is registered.

Even though NYSE Rule 460.10 refers to business deals with a company, it appears clear that it, as well as Rule 401, applies to dealings with an insider in view of the absolute necessity of insulating the specialist from material conflicts of interest. See also NYSE Rule 113.

111. 17 C.F.R. $\$ 240.11$ b (1970).

112. NYSE Rule 104 provides:

No specialist shall effect on the Exchange purchases or sales of any security in which such specialist is registered, for any account in which he, his member organization or any participant therein is directly or indirectly interested, unless such dealings are reasonably necessary to permit such specialist to maintain a fair and orderly market, or to act as an odd-lot dealer in such security. 
$104.10^{113}$ to maintain a "fair" market. Moreover, he has clearly violated the letter as well as the spirit of NYSE Rules 401 and $460.10^{114}$ and 105..$^{115}$ The Rule 104 duty to maintain a "fair" market requires him to be free of any conflicts of interest which would lead him to make a market in a stock to feather his own nest to the detriment of the public, and forbids him from withholding msider news to the detriment of the public even if he is not profiting thereby. ${ }^{116}$ In this variation of the illustration plaintiff would argue that the specialist violated NYSE Rules 104, $104.10,105,401$ and 460.10 and that such violations were the proximate cause of plaintiff's injury in view of his interest in the stock's decline. ${ }^{117}$ The specialist might argue that the duty to maintain a "fair" market is too vague to support liability. However, since the requirement to maintain a fair and lonest market is mandated by an exchange rule which is explicitly required by a Commission rule and is absolutely central to adequate specialist performance, it would appear that plaintiff should prevail, especially since, if fairness means anything, it precludes a specialist's secret interest in a company in whose stock he specializes.

Finally, suppose a third alternative. On several days the specialist engages in a course of dealings which are allegedly in gross violation of

113. NYSE Rule 104.10 provides in relevant part:

Any member who expects to act regularly as specialist in any listed stock and to solicit orders therein must be registered as a regular specialist.

The function of a member acting as regular specialist on the Floor of the Exchange includes, in addition to the effective exccution of commission orders entrusted to him, the maintenance, in so far as reasonably practicable, of a fair and orderly market on the Exchange in the stocks in which he is so acting.

114. For text of NYSE Rules 401 and 460.10 , see notes 109 \& 110 supra.

115. NYSE Rule 105 reads in part: "No member acting as a specialist and no member organization in which such a member is a participant . . . shall ... directly or indirectly hold, acquire ... or have an interest in any option to buy or sell ... shares of a stock in which such a member is a specialist."

116. See Wolfson \& Russo, supra note 21 , at 726-27. The NYSE takes the following position:

The specialist is charged with doing all that is in his power to give the company and its stockholders the fair and orderly market that is expected from a listing on the Exchange. To do this effectively, he must maintain proper liaison with the company's officials. Properly conducted, such liaison should foster a mutually beneficial understanding of the problems encountered by both. Company officials should be kept informed of any unusual market problems and are free to call on the specialist for information if a question arises about the market in the stock. The specialist, for his part, gains from a better understanding of the coinpany and its affairs.

There is, of course, a point beyond which it would be improper for the company to go in giving information to the specialist. Thus, for the corporation to give advance earnings, dividend, stock split, or merger information to a specialist or anyone else would be clearly inappropriate.

New York Stock Exchange, Company Manual A-21 (1968).

117. The specialist may possibly be sued on the ground that he was participating in violation of rule 10b-5. See United States v. Re, 336 F.2d 306 (2d Cir. 1964.) 
his duty to maintain an orderly market. ${ }^{118}$ For example, on the three days in question, he permits the stock to drop from 35 dollars to 15 dollars while purchasing a negligible amount of stock for his own account. Plaintiff sells his stock at 15 dollars and then sues the specialist. Plaintiff alleges that the specialist has violated NYSE Rules 104 and 104.10 and that the violation was the proximate cause of the price drop. The specialist argues as follows: His performance was satisfactory, but even if it were not, the stock would have dropped to 15 dollars, or at least to 16 dollars regardless of how hard he tried due to general market conditions and adverse news about the company: moreover, the exchange standards for performance are too vague to justify the harsh penalty of civil liability. The evaluation of a specialist's performance is not always easy simce admittedly the tests for adequate specialist performance fall short of litmus paper exactitude. However, if in fact the specialist's performance was bad enough to constitute a negligent violation of his duty under the rules in question, plaintiff sliould prevail. ${ }^{110}$ Here again the exchange rule in question was a substitute for a Commission rule. Of course if the specialist also is shown to have a personal interest in the stock's decline-for example, because of a secret short account in the naine of his wife or hidden interests in hedge funds in violation of NYSE rules ${ }^{120}$ - the case for plaintiff's recovery is much stronger. Finally, when the specialist is found to have violated the exchange rules, he should have the burden of proving that the stock did not drop to 15 dollars as a result of the violation.

\section{CONCLUSION}

The imposition of liability in accordance with the test proposed

118. See notes 112 \& 113 supra.

119. For a discussion of performance standards of specialists see Wolfson \& Russo, supra note 21, at 736-37. In addition to the example in the text, another example of clear cut poor performance by a specialist would be the following: Specialist opens day with a zero position in $X Y Z$ stock. The closing price on the previous day was 51 . The public enters seven sell orders between 10 a.m. and noon, each one of which is for 100 shares. The specialist buys no stock for his own account and instead buys in each case for his book-for public orders-in descending prices of $50,50,491 / 8$, $481 / 2,473 / 8,47,46$. This is an obvious case where the specialist has "let go" of the stock-failed to fulfill his affirmative duty under Rule 104.10 to enter the market for his own account to supply continuity with depth to the market in the short run. Thus the specialist should have prevented his specialty stock from falling as sharply as it did by entering the market as a dealer and his failure may well subject him to successful civil liability suits.

120. NYSE, Educational Circular No. 313, Sept. 29, 1970, discussed the applicability of certain NYSE rules to investinent partnership or "hedge funds." Among the rules discussed was NYSE Rule 94 which would prohibit a specialist from participating in a hedge fund which bought or sold any security in which the speciahist was registered. Id. at 2. The Amex had made a similar interpretation of their analogous rule [Amex Rule 175] a year earher. Amex Information Circular No. 79-69, at 8-9 (Apr. 25, 1969). 
above will assure that exchange rules are vigorously enforced in furtherance of the purposes of the 1934 Act. Civil liability will enable the public investor to gain proper monetary redress against melnber firms and will serve as a valuable method of preserving or restoring the vigor of self-regulation. Also, given the failures of self-regulation, there is reason to doubt the efficacy of exchange disciplinary proceedings as a substitute for private actions and as a sufficient inethod for assuring proper self-regulatory vigor. ${ }^{121}$ Moreover, the in-terrorein effect of the civil liability cases under Commission rule 10b-5 in an indication of the propliylactic value of civil liability for violation of exchange rules. ${ }^{122}$

As has been shown, there appears to be no due process impediment to imposing implied civil liability on member firms for violation by them of exchange rules. ${ }^{123}$ However, to better enable the public to have a voice in structuring the rules which are or should be adopted to benefit them the exchanges might consider a change in the method of promulgating their rules. Currently, under Commission rule

121. In a recent speech, Commissioner James Needham stated:

It is worth noting, at this point, that during times of financial difficulty, the self-regulatory apparatus of the securities industry has appeared to function at something less than full efficiency. It is not easy to upgrade business standards and practices when a consensus is necessary, but that is what self-regulation requires-and more importantly, what the public interest demands. Timidness, compassion, or "flexibility" are not substitutes for objectivity in the interpretation and enforcement of one's own rules. I wonder which of those firms that have gone under because of financial difficulties would still be in business today if there had been more vigorous and foresighted regulation of their financial and operational capacity by those charged, im the first instance, with regulatory responsibility. The Securities Act of 1934 lodged such responsibility in national exchanges; therefore, it is they and their members who must account for their stewardship of the public interest.

Address by Commissioner Needham, Second Annual Management Conference of the Association of Stock Exchange Firms, Sept. 9, 1970.

In a highly controversial speech on November 17, 1970, Robert Haack, president of the NYSE, called for changes in the Exchange to eliminate any aspect of a "private club." N.Y. Times, Nov. 18, 1970, at 1, col. 3. The president of the Amex, Ralph Saul, has set forth the following goals:

1. Develop organization and methods to coordinate industry operating systems, eliminate duplication, and make more efficient use of existing resources.

2. Reverse the continuing fragmentation of the central markets, often encouraged by regulatory policies, that works to the disadvantage of the public and the industry.

3. Develop better methods for bringing the views of the major elements involved in our markets into the decision-making processes.

4. Develop, in cooperation with government, agreement on major public policy objectives so that the securities industry can plan with greater certainty and the self-regulators can exercise their responsibilities more effectively. R. Saul, Memorandum to the Menbership of the American Stock Exchange 3, Nov. 16, 1970.

122. See 2 L. Loss, supra note 31 , at 2887-91.

123. See text accompanying notes 61-69 supra. 
$17 a-8,{ }^{124}$ exchange rules are filed privately with the Commission three or more weeks before their effective date. The Commission staff comments are generally circulated privately to the exchanges. On the other hand, Commission rule proposals must be announced publicly and comments of interested persons are invited and are generally maintained in a public file. ${ }^{125}$ It might be advisable for the exchanges also to publicly announce rule proposals-other than the "lousekeeping" variety ${ }^{120}$-and invite public comments. Similar methods were followed by the Commission in connection with recent exchange rule proposals involving public ownership of member firms. ${ }^{127}$

The 1934 Act contains approximately 50 separate references to the goal of the "protection of investors." The imposition of implied civil liability for violation of stock exchange rules weds goal to result and theory to practice. It affords redress to the public and a convincing stimulus to effective self-regulation.

124. 17 C.F.R. $\$ 240.17$ a-8 (1970). See generally 2 L. Loss, supra note 31 , at 3151-53.

125. See Administrative Procedure Act $\$ 4,5$ U.S.C. $\$ 553$ (1964).

126. See Lowenfels, supra note 24, at 24-30.

127. See SEC Securities Exchange Act Release Nos. 8734 (Oct. 29, 1969), 8753 (Nov. 17, 1969), \& 8849 (Mar. 26, 1970). 


\title{
California Law Review
}

\begin{tabular}{lll}
\hline \hline VoL. 58 & OCTOBER 1970 & No. 5 \\
\hline \hline
\end{tabular}

\section{BOARD OF EDITORS}

\author{
Editor-in-Chief \\ JOSEPH T. KIEFER \\ Chief Managing Editor \\ ROBERT D. EvaNs
}

Notes \& Comments

KeNT Sinclatr, JR.

D. Rebecca SNow

Peter J. Aschendrenner

JAMES R. FARRAND

PAUL E. Gilbert

PaUl W. GlenN

MiChAEL L. MEXERS

Bruce S. Ross

KeNT A. RusSELl

JAMES TOLEDANO

MERRICK JOHN BOBB

Winltam M. ChamberlatN

Diane D. Eames

ROBERT ERICSON

GENE HARTER

ELLyn A. Hershman

DAVID M. ACHTERKIRChEN

ROBERT C. BARRETT

STEVEN A. BRICK

LAWRENCE R. BROWN

MARY Jo CHRISTENSEN

JoHN F. DAVIS

STEVEN M. DRUKER

HENRY C. EAMES, JR.

AUBAN ANN EISENHARDT

CHARLES R. FARRAR, JR.

\section{Articles}

WIILIAM F. COOK

Steven Finell

Maria Tankenson

\section{Managing}

DaRVISH M. KoRdESTANI

Mrchael George Kozak

Book Reviews

J. Michael BrenNaN

MARY DUNLAP

\section{Associate Editors}

JUDITH G. KLEINBERG

JoHN E. MASON, JR.

Robin MEaDow

Dodglas Alan Oglesby

LAWRENCE B. ORDOWER

RICHARD L. PARRISH

Second Year

JAMES C. FOWLER

HAROLD FRIEDMAN

CAROL G. HAMMETT

DAVID L. HAMMETT

JIMMIE HARRIS

ROBERT I. HARRIS

SPENCER R. KATTZ

DENNIS S. KaRJALA

SheIla S. Kato

RICHARD MARCUS

THOMAS M. MURRAY

Administrative Aide Susan G. Vega
Research

G. KIP EDWARDS

DAVID R. ANDREWS

Chardes H. HuRd

Douglas M. Laurice

ROBERT LEVY

Supreme Court Editor

GREGORY J. HOBBS, JR.

Executive Editor

WiLLIAM BILLINGSLEA, JR.

RICHARd L. PEREZ

OMar Petrona

Peter E. Sheehan

MARGaRet SHERWOOD

MichaEl B. STMON

Robert D. Stratmore

CAROl Bruch Myers

Elaine T. Nelson

LYNN H. PASAHOW

REX PERSCHBACHER

THOMAS B. ROSENBERO

ROBERT K. SCHIEBELHUT

Mark Harold Shenfield

SUSAN J. TAMURA

SCOTT R. WILLERT

STEPHEN ZAMORA 